\title{
The Impact of the Trump Doctrine on Syria
}

\section{Salih Omar Issa}

Department of Diplomacy and International Relations, Collage of Political Sciences, Salahadin University, Erbil- Iraq

salihomarissa@yahoo.com

\section{Chenar Babaker Mohammed}

PhD student International relations, College of Law and International relations, Soran University, Erbil- Iraq

Cbm01h@irel.soran.edu.iq

\section{ARTICLE INFO}

\section{Article History:}

Received: 26/6/2020

Accepted: 17/8/2020

Published: Summer 2020

\section{Keywords:}

Trump

Doctrine,

Syrian Crisis,

Protecting Israel,

Curbing Iranian role

Doi:

10.25212/Ifu.qzj.5.3.33

\begin{tabular}{l} 
ABSTRACT \\
\hline United States foreign policy has sought to maintain \\
primacy on the global stage, but every U.S. president \\
has maintained U.S. foreign policy in their own context. \\
Counter to previous administrations, President Donald \\
Trump has focused U.S. foreign policy through the lens \\
of transactional realism concentrating on \\
counterterrorism and challenges to U.S. interests and \\
allies in the Middle East. Trump has criticized his \\
predecessors for their policies of deep engagement \\
leading to a deterioration of U.S. 'Greatness,' wasted \\
tax dollars, and wasted American lives. Rooted in his \\
background as an entrepreneur, President Trump has \\
centered foreign policy around "America First." \\
However, U.S. interests in Syria are complicated by a \\
multitude of actors involved in the Syrian conflict. \\
Consequently, President Trump utilizes smart power \\
with limited engagement in Syria based on cooperation \\
with regional and international actors, particularly with \\
regards to the 'War on Terror.' This strategy focuses on \\
working with Russia, even if concessions are necessary, \\
to curb Iran's role in the region while protecting long- \\
time ally, Israel. Furthermore, the United States exerts
\end{tabular}




\section{QALAAI ZANISTSCIENTIFIC JOURNAL}

A Scientific Quarterly Refereed Journal Issued by Lebanese French University - Erbil, Kurdistan, Iraq

Vol. (5), No (3), Summer 2020

ISSN 2518-6566 (Online) - ISSN 2518-6558 (Print)

limited engagement through Syrian Kurdish forces in the region to maintain its strategy in Syria.

\section{INTRODUCTION}

After the Arab Spring in 2011, the transformation of government and ruling in some Arab states has concerned regional and international actors. Among such, the United States has remained as main actor in the Middle East. This engagement is for the purpose of preserving its interests and protecting its allies in the region. Despite the Trump presidency's transactional language and withdrawal from many international agreements, U.S. policy in the region still follows previous administrations' strategy of primacy and leadership in the region. Through the short-term strategy of economic achievement and bargaining, Trump has maintained engagement with the international community.

The research significance is to show the way President Trump deals with Syrian affairs under the business morality and within the framework of transactional Realism. Moreover, in his perspective, America is not bound to stay in a place where it is not in the U.S. interests. Trump's business language has brought a new era to the U.S. foreign policy.

However, the research aims are to show the U.S. foreign policy toward Syria under the Trump administration. A president with business rhetoric and transactional behavior could impact on U.S. foreign policy toward Syria. The state of Syria has the Kurdish populations who are U.S. allies in the War on Terror and are the neighbor of the Kurdistan Regional Government. This paper could serve those interested in pursuing U.S. foreign policy in Syria, where Kurds involved and could impact the Kurds in KRG. Moreover, the paper presents academic information for the KRG decision-makers who can draw the policy regarding U.S./Kurdish relations in the future.

The question of research paper is what will be the impact of the Trump Doctrine on Syria?

The research hypothesis; President Trump does not seek to regime change and, since there are many actors involving in Syria, the Trump administration is maintaining its policy of cooperation with local, regional, and international actors. The Trump administration does not seek intense direct engagement but, rather, allows other actors to take part in Syrian political solutions. The involvements of many actors make reaching a political solution in Syria difficult. Despite this, Trump 


\section{QALAAI ZANISTSCIENTIFIC JOURNAL \\ A Scientific Quarterly Refereed Journal Issued by Lebanese French University - Erbil, Kurdistan, Iraq \\ Vol. (5), No (3), Summer 2020 \\ ISSN 2518-6566 (Online) - ISSN 2518-6558 (Print)}

seeks to protect U.S. interests and Israel from any threats. Consequently, the Trump administration is struggling to curb the role of Iran and its affiliates in Syria.

The methodology of research paper, using hermeneutics, will focus on U.S. support of local and foreign powers to manage U.S. interests with the aim of examining the Trump Doctrine on Syria. Due to Trump's incoherent and inconsistent policy, this paper will analyze Trump's statements in context to arrive at a comprehensive understanding of the US foreign policy in Syria. Furthermore, the qualitative method has been used for analyzing research data.

The structure of the research paper contains four parts, excluding the introduction and conclusion. The first section illustrates the independent variable of research, which is the Trump doctrine and its theoretical background, and the national and security strategy of his administration. The second section is a dependent variable, which is Syria. It includes the Arab springs, state division, and Kurdish issues. The third section covers the regional and international intervention in the Syrian interior affairs. The last section contains analyzing the Trump doctrine and its impact on Syria, under the transactional realist approach by applying smart and soft power.

\section{The Trump Doctrine}

In the history of United States, presidents have pursued their own doctrine for domestic and foreign policy. Doctrines are not simply rhetoric, but are statements made by presidents to specify the "highest policy", especially in time of chaos and crisis (Colucci, 2012: 4). It is a presidential language for communicating policy to domestic and foreign audiences as well as adversaries and allies. This kind of language can be misleading, and it must be outlined in detail to be applied to foreign policy. The significance of presidential doctrine is observed when it becomes a productive mechanism for foreign policy rather than shaping agitation and malignity (Michael, 2011: 492).

During his presidential campaign, Donald Trump, as a businessman, criticized politicians for talking too much without practical action. This "all talk, [and] noaction" stance shaped his perception that businesspeople should take office and resolve the problems created by politicians. According to Trump, politicians brought great problems to the United States and this cannot be fixed any longer by political rhetoric but by "common sense." Donald Trump used business rhetoric in his campaign and called himself a winner, a leader, and the person who can inspire others to choose a way of success and progress in their life (Trump, 2015: 22-29). 


\section{QALAAI ZANISTSCIENTIFIC JOURNAL \\ A Scientific Quarterly Refereed Journal Issued by Lebanese French University - Erbil, Kurdistan, Iraq \\ Vol. (5), No (3), Summer 2020 \\ ISSN 2518-6566 (Online) - ISSN 2518-6558 (Print)}

The Trump Doctrine can be viewed as the amalgamation of many thoughts. Through a framework of realism, he emphases military capabilities and zero-sum achievement through economic gains. However, his doctrine also omits some of the value-based rhetoric and includes neo-conservative ideas of "Ideational basis" on civilization and the threat of terrorism on civilization. The Trump administration's actions can be best described as "transactional realism." President Trump's doctrine is combination of U.S. grand strategies of deep engagement, liberal hegemony, retrenchment, and foreign balancing. He does not get deeply involved but also does not isolate from international affairs (Sinkkonen, 2018: 4-12). In his transactional policy in dealing with world affairs Trump says 'they' must pay us in remarks made in a briefing at $\mathrm{Al}$ Asaad Air Base.

"We don't want to be taken advantage anymore by countries that use us and use our incredible military to protect them. They don't pay for it, and they're going to have to.... I'm talking about all over the world. Wealthy countries cannot expect the United States to pay for a vast majority of their military. They can pay us. They can reimburse us." (Trump, : 2018a)

With regards to the military intervention, Trump believes that U.S. involvement in conflict was wrong, for instance Vietnam, during the Iraq invasion, and Libya after the Arab Spring. President Trump distinguishes; these were a "disaster, big mistake, and total mess." With regards to the ISIS threat, Trump said that 20,000 to 30,000 troops can eliminate the ISIS threat, but these troops won't be US troops. Therefore, He will not involve U.S troops, as for him, "people from that part of the world... will have to put up the troops" (Trump, : 2016b).

Therefore, under the economic bargaining and business principals, president Trump pursues the U.S. foreign policy in the world. He enumerates and details the costs of U.S. involvement in the world. He seeks to prevent the United States from losing its lives and money in the place which is not in U.S. interests.

\subsection{National Security Strategy (NSS) and National Defense Strategy (NDS)}

The Trump administration's NSS and NDS indicate the international system is out of order as well as a decline of U.S. strategy. The United States' military capacity is being challenged by Russia and China and major actors in the international community are competing to gain international primacy. The strategies also indicate the importance of the United States leading the world through military strength, decreasing Russian and Chinese global military capabilities, diminishing the role of Iran in the Middle 


\section{QALAAI ZANISTSCIENTIFIC JOURNAL \\ A Scientific Quarterly Refereed Journal Issued by Lebanese French University - Erbil, Kurdistan, Iraq \\ Vol. (5), No (3), Summer 2020 \\ ISSN 2518-6566 (Online) - ISSN 2518-6558 (Print)}

East, stopping the North Korea nuclear program, and eliminating the presence of terror (Sach, 2018: 115-119).

Both strategies of the Trump administration focus on the United States' exceptionalism and "America First" through military dominance by strengthening its power in military capacity in the world. However, according to the Gallup report in 2018, U.S. military leadership has declined from 48 percent in 2016 to 30 percent in 2017. China's leadership was maintained "steadily 33 percent" during the same period (ibid: 121).

The world is filled with many nation-states competing for global significance. This "power" is sought after through the control of the air, land, sea, and, in the modern age, the cyber world. Through military, economic, and diplomatic tools, nations reach for supremacy. The NDS is concerned about "revisionist powers" such as Russia and China as a part of the threat to U.S. security and prosperity (Sinkkonen, 2018: 11) . Both the NSS and NDS strategies are less focused on American values like liberty and human rights and instead more on U.S. interests (Larres, 2017).

The Trump defense strategy also focuses on the modernization of the military and strengthening alliances and partnerships as well as reforming the U.S. Department of Defense. Modernizing the military is not something new to U.S. strategy and has been central to policy since the Vietnam War. Trump's focus for strengthening alliances is evidenced in his attempt to have NATO members to pay their share of defense to the United States. The NDS calls for "more lethal, resilient, and rapidly innovating Joint Force, combined with a robust constellation of allies and partners" to "sustain American influence and ensure favorable balances of powers" (Grieco, 2018: 3-6) .

To strengthen partnerships, U.S. Secretary of State, Pompeo, visited the Middle East in January 2019 and met leaders to seek more allies among Arab countries, especially in the Persian Gulf. In his tweet Pompeo mentioned: "Heading to the Middle East today to send a clear message to our friends and partners that the U.S. is committed to the region, committed to \#defeatISIS, and committed to counter Iran's destabilizing activities" (Pompeo, 2019a). President Trump also mentioned in his tweet that the U.S. seeks to build new partnerships and alliances to counter challenges in the region.

Since the end of the Cold War, the U.S. has maintained primacy through military intervention to shape the world order. The grand strategy of U.S. primacy has been 


\section{QALAAI ZANISTSCIENTIFIC JOURNAL \\ A Scientific Quarterly Refereed Journal Issued by Lebanese French University - Erbil, Kurdistan, Iraq \\ Vol. (5), No (3), Summer 2020 \\ ISSN 2518-6566 (Online) - ISSN 2518-6558 (Print)}

applied for 30 years in the NSS and NDS of the United States by increasing the role of the military and spending a lot on defense systems (Grieco, 2018: 7).

\subsection{The Previous Administrations in the Trump Perspective}

Firstly, under the Bush administration, the War on Terror was started in the name of promoting democracy and human rights. However, Donald Trump, in his presidential campaign rhetoric, called it a "terrible thing." In Trump's perspective, more terrible than the Bush administration's act of engaging in war was the Obama administration's withdrawal of troops from Iraq which left a vacuum for terrorist organizations to grow and strengthen (Stocker, 2018: 261). Trump rejected both the Bush and Obama doctrines and has approached world issues with a "Hobbesian Realism" and "Zero-sum personality" (Nye, 2019: 70).

Secondly, in discussing U.S. policy towards Israel, Trump stated in his speech on March 22, 2016 in AIPAC that what President Obama gets wrong about deal-making is that he constantly applies pressure to our friends and rewards our enemies." Trump condemned President Obama and Secretary of State Hilary Clinton for their poor treatment of Israel saying, "She and President Obama have treated Israel very, very badly." Furthermore, Trump criticized the United Nation's Iran deal and also stated that Palestinian society has a "culture of hatred" (O'Toole, 2016). Trump even blamed the United States' attitude in the Security Council condemnation of Israeli settlement activity on December 16, 2016. Taking this a step further, on November 18, 2019, Secretary Mike Pompeo formally announced U.S. policy toward the Israeli settlement in West Bank as legal (Pompeo, : 2019b).

On January 28, 2020, Trump in a joint meeting with Israeli Prime Minister Benjamin Netanyahu, announced a two-state solution in the Middle East Peace plan as a "winwin" solution to the conflict (Trump, 2020c). This plan was later refused by Mahmud Abass who said, "we say a thousand no's to the Deal of The Century," (Abbas, 2020). Thirdly, with regards to the Nuclear deal with Iran, President Trump noticed that the Joint Comprehensive Plan of Action (JCPOA) was a disaster and provided more opportunities for Iran to be aggressive in the region while promoting its nuclear program. During the Obama administration, Iran became stronger and did not adhere to the nuclear deal. Additionally, Iran threatened Israel's security in the region. Trump called JCPOA a "disaster" and placed more sanctions on Iran in October 2017. Further, Trump ordered the withdrawal from the Nuclear Deal with Iran under JCPOA (Gause, 2018. P. 275 \& Stocker, 2018. P. 269). After withdrawal 


\section{QALAAI ZANISTSCIENTIFIC JOURNAL \\ A Scientific Quarterly Refereed Journal Issued by Lebanese French University - Erbil, Kurdistan, Iraq \\ Vol. (5), No (3), Summer 2020 \\ ISSN 2518-6566 (Online) - ISSN 2518-6558 (Print)}

from the deal on May 8, 2018 (Trump, 2018c), Trump formally labeled the Iran Islamic Revolutionary Guard Corps (IRGC) as a Foreign Terrorist Organization (FTO):

"Today, I am formally announcing my Administration's plan to designate Iran's Islamic Revolutionary Guard Corps (IRGC), including its Quds Force, as a Foreign Terrorist Organization (FTO) under Section 219 of the Immigration and Nationality Act (Trump, : 2019a)

Lastly, Trump has challenged or withdrawn from international institutions that were established after the Second World War either because parties to these institutions do not adhere to the guiding principles or because others do not pay their share of the burden. While in the first months of his presidency, Trump viewed NATO as "Obsolete" (Trump, : 2016a). Trump would later retract that stance due to the dependence on allies in fighting terrorist groups such as ISIS and Al-Qaeda. However, Trump maintained that member states of NATO must pay their fair share (at least $2 \%$ of their defense budget) according to their GDP. So, they must "meet the obligations" (Larres, 2017). Trump reiterated this point at the NATO Summit on December 3, 2019, saying that NATO members should pay their fair share of NATO spending noting that the U.S. share was much higher than that of other members at $3.5 \%$ of its GDP (CNBC, 2019).

Besides NATO, Trump withdrew the U.S. from the Transpacific Partnership (TPP) on the $23^{\text {rd }}$ of January 2017. This partnership was formed under the Obama administration to decrease tariffs and intellectual property disputes between the U.S. and some nations in Southeast Asia. However, President Trump viewed this as a matter of trade deficiency (Woodward, 2018: 139-140) (Branett, 2018: 12).

On February 2, 2019, the Trump administration announced its withdrawal from the INF treaty proclaiming Russian violation non-compliance.

"The United States has adhered to the INF Treaty for more than 30 years, but we will not remain constrained by its terms unless Russia comes into verifiable and enforceable compliance." (Pompeo, 2019c)

Trump also announced "in order to fulfill [his] solemn duty to protect America and its citizens, the United States will withdraw from the Paris Climate Accord" (Trump, 2017). 


\section{QALAAI ZANISTSCIENTIFIC JOURNAL \\ A Scientific Quarterly Refereed Journal Issued by Lebanese French University - Erbil, Kurdistan, Iraq \\ Vol. (5), No (3), Summer 2020 \\ ISSN 2518-6566 (Online) - ISSN 2518-6558 (Print)}

\section{Syria after 2011}

\subsection{Arab spring and domestic crisis}

Because of inequality and the violation of human rights, civil unrest, demonstrations against authority and a demand for reform emerged from the Arab Spring in 2011 in Tunisia, Egypt, Yemen, Libya, and Bahrain. The Arab Spring found its way to Syria in March of 2011. Among the demonstrators were urban, displaced citizens and the young generation who demanded freedom. In Syria it sprang from Hama, Homs, and Dera'a. They call for freedom and change. The response to such demands were suppressing, torturing, and killing civilians. In June 2011, the government killed 1.400 civilians and arrested another 10,000 in Dera'a (Davis, 2015: 65-67).

Protesters in Syria thought they would be able to overthrow the Syrian regime like what civilians accomplished in Libya and Egypt with international support. Contrary to the toppling of Gaddafi and regime change in Libya, the Syrian Regime led by Bashar al-Assad has been supported externally with the supply of weapons in addition to being in possession of chemical weapons. The existence of sectarian groups with different, opposing policies has led to disunity in the fight to counter the Assad regime. Furthermore, the silence of the international community and the Arab League in responding to the tension is a flashpoint in the Syrian conflict contributing to the maintenance of Assad's regime. The Arab spring in the other Arab countries resulted in regime change supported by military intervention and the creation of 'no-fly' zones. However, in Syria, the international community did not intervene. The international community did work towards negotiations for ceasefire and placed sanctions on the Syrian regime, but, with support from external actors, the Assad government has remained in power (Buckley, 2012: 82-90). In addition to the domestic conflict and foreign intervention, the emergence of ISIS in both Syria and Iraq further complicated the situation. The international response pivoted under the "War on Terror" to focus on fighting the ISIS insurgency.

\subsection{State division and humanitarian crisis}

Because of the Uprising, emerging instability, and civil war, Syria divided into many areas under different sectarian control. The areas which are outside the central government have been divided under the control of the Syrian Democratic Force (SDF) in the northeast and the Turkish controlled opposition groups in the northwest. The SDF seemed not to threaten the regime. In Idlib province, in the southwest of Syria, the oppositions and rebels work towards regime change. In the Turkish controlled areas, Turkey intervened militarily and launched an Operation Euphrates 


\section{QALAAI ZANISTSCIENTIFIC JOURNAL \\ A Scientific Quarterly Refereed Journal Issued by Lebanese French University - Erbil, Kurdistan, Iraq \\ Vol. (5), No (3), Summer 2020 \\ ISSN 2518-6566 (Online) - ISSN 2518-6558 (Print)}

Shield in the city of Aleppo in northwestern Syria to eliminate ISIS and the Kurdish YPG in late 2016 (Ratney, 2018: 54-57).

The destruction blanketed the country. As a result of the internal and external factors in Syria, solution to the conflict became more difficult. Internally, these complications stem from three groups-those aligned with the regime, those that are not aligned to the regime, and those that actively oppose the regime. Each of these groups has external support thereby complicating the situation further. Syria has morphed into a battleground of confrontations (Jeffrey Martini et al, 2013: 7-9). In 2018, reports from the Syrian Observatory for Human Rights (SOHR) estimated the civilian death toll since the start of the war to be as high "as 511,000 as of March ..." The United Nations High Commissioner for Refugees (UNHCR) reports 6.6 million internally displaced persons (IDPs) and 5.6 million refugees spread around the world ${ }^{1}$ (HRW, 2019). During the offensive operation of the Assad regime in 2018, 1.6 million civilians were displaced in the northern governorate of Syria, in Hama and Idlib, in the southern governorate of Dera'a and Quneitra, and in the eastern Ghouta in Damascus. Syria has been recorded as the country with the largest number of IDPs globally (IDMC, 2018).

\subsection{Kurdish issue}

The Kurdish national movement in Syria began a century ago and Kurdish parties developed in suffrage for their political rights. After the Uprising in Syria, the Kurdish parties that believed in Kurdish self-determination sought to achieve their national rights and formed the Kurdish National Council (KNC) in Qamishli on October 26, 2011. The goal of the council was to promote their agenda for the Kurdish future in Syria. The KNC, comprised of 16 parties, promoted a program for a democratic and pluralistic parliamentary Syria. Further, the council pushed for the recognition of Kurdish communities as essential in the country. On April 21, 2012, the KNC held their first conference in the city of Erbil in the Kurdish Region of Iraq and adopted a transitional program in Syria (KNC, : 2019).

When Syrian forces were unable to maintain control of the Kurdish territories, they receded to the controlling center as well as Homs and Hama in the south. After the

1 According to UNSC Resolution 2449 (2018), the internally displaced totally registered to 6.2 million. And 5.6 refugees to the neighboring countries among them 4.2 million are women and children (See: Transparency International, 2018a). 


\section{QALAAI ZANISTSCIENTIFIC JOURNAL \\ A Scientific Quarterly Refereed Journal Issued by Lebanese French University - Erbil, Kurdistan, Iraq \\ Vol. (5), No (3), Summer 2020 \\ ISSN 2518-6566 (Online) - ISSN 2518-6558 (Print)}

regime withdrew from the area in July 2012, PYD (Partiya Yekîtiya Demokrat/The Kurdish Democratic Union Party) with its military arm, the YPG (Yekîneyên Parastina Gel/The People's Protection Unit), took authority in that area until 2014. They found the opportunity to rule themselves with a military structure, local council, and access to resources such as dams on the Tigris and Euphrates rivers, access to the cities of Hassakeh, Raqqa, and Der ez-Zur, and oil drilling facilities (Davis, 2015: 68). They declared Afrin, Kobane, and Jazeera as three cantons. Their political system was based on self-governed administration at least until the crisis in Syria was resolved (Schøtt, 2017: 17).

During counterterrorism efforts against ISIS, the U.S. coalition supplied the PYD and YPG with weapons to fight the "War on Terror." Kurds in Northeast Syria established the Syrian Democratic Force (SDF). While the PYD and YPG make up the dominating group, the SDF is a combination of different ethnicities including Arabs, Turkmen, Armenians, and Assyrians, among others. This non-state actor is identified as the most united actor in Syria. As opposed to other forces in Syria, the SDF, established in October of 2015, focuses on a non-threatening agenda to secure autonomy and a "secular, democratic, and federal Syrian Republic" (Ratney, 2018: 54-55). In March of 2016, the PYD declared self-governance in the context of a federal Syria. However, on the Syrian-Turkish border, the Turkish government displayed disagreement with this arrangement (Martin, 2018: 96-97).

\section{Regional and International Intervention}

\subsection{Iran}

Relations between Iran and Syria are like their relations during post-revolutionary Iran in 1979. Despite Syria being ideologically different, they have fortified their relations up to the present. This relationship is forged in common foreign policy priorities - anti Saddam in Iraq and Israel as a common enemy. During the Iran-Iraq war, Syria supported Iran with its rhetoric, military forces and transferring aid. Efforts of other Arab countries in the region to curb the Assad regime's support of Iran were useless (Terrill, 2015: 222-227).

Since the emergence of the Arab Spring in 2011, Iran's foreign policy has sought to keep Assad in power to maintain its influence in the region. Civilian protests to overthrow the Assad regime and emerging armed oppositions brought Syria to the forefront of Iranian foreign policy due to its strategic importance to the region. Iran continued its financial, technical, and logistical support of the regime. Under the leadership of Major General Qasim Suleyman of Iran's Revolutionary Guard Corps 


\section{QALAAI ZANISTSCIENTIFIC JOURNAL \\ A Scientific Quarterly Refereed Journal Issued by Lebanese French University - Erbil, Kurdistan, Iraq \\ Vol. (5), No (3), Summer 2020 \\ ISSN 2518-6566 (Online) - ISSN 2518-6558 (Print)}

(IRGC), the Syrian military received support and aid such as weapons and military personnel and supervisors (Martin, 2018: 93-94).

After the collapse of Saddam Hussein's regime, Iran gained the opportunity to further pursue its ambitions in the region including intervention in Iraq and beyond in Yemen, Lebanon, and the Gaza strip (through its support of Hamas, a group akin to the Muslim Brotherhood). Additionally, Iran sees Syria as "Near Abroad" to its expansionist policy in the region. What is important is for Iran to fulfill its goals in any way possible. Supporting proxies in the region is a direct threat challenging the Arabs states, Israel, Turkey and western countries (Al-Istrabadi, 2018: 177-182).

In 2016, three thousand IRGC forces participated in the Battle of Aleppo alongside Russia and the Assad regime to counter the threat of Sunni groups taking power in Syria, which would deteriorate Iran's position in the region. Iran stands with the Assad government militarily in curbing opposition rebels in Syria. Despite a ceasefire agreement between Iran, Turkey, and Russian, eight thousand Hezbollah combatants supporting Assad remain in Syrian territories and continue to fight (Jones, 2019: 3). The existence of ISIS and Assad's fight against it favors the Iranian position and demonstrates to the international community that ISIS is an endemic threat for the whole world. The existence of this threat and Assad's actions against it impacts the world perspective of removing Assad from power. The global opposition toward the Assad government is loosened and thereby further strengthens Assad's hold on power because the Syrian government claims they are fighting the War on Terror (Terrill, 2015: 229-236).

\subsection{Turkey}

When Syrian Kurds sought autonomy under a federalized government, the Turkish government viewed this as a threat due to the potential consequences such an arrangement would have on the Kurdish population in Turkey, which is a direct neighbor to the Kurdish region established in Syria by the SDF. Turkey opposes any form of Kurdish self-governance and is aware of Kurdish forces' capability to self-rule and Kurdish demands for autonomy within a federalized state of Syria. The PYD controls nearly 25 percent of the Syrian territory dubbed Rojava that includes the three cantons of Afrin, Kobani and Jazira (VOA, 2018).

The reality of potential calls for autonomy among its own Kurdish population created a sense of urgency and threat to the Turkish government which prompted Turkey to focus its intervention on Kurdish forces in Syria instead of fighting ISIS. Turkish foreign policy, therefore, disagrees with the U.S. and coalition forces 


\section{QALAAI ZANISTSCIENTIFIC JOURNAL \\ A Scientific Quarterly Refereed Journal Issued by Lebanese French University - Erbil, Kurdistan, Iraq \\ Vol. (5), No (3), Summer 2020 \\ ISSN 2518-6566 (Online) - ISSN 2518-6558 (Print)}

supplying the YPG and PYD with arms. To Turkey, the fear of an autonomous Kurdish region south of its border led by a group it labels as a part of PKK (Kurdistan Worker's Party/Partiya Karkerên Kurdistanê) was and is their greatest threat. Turkey, therefore has accused U.S. and coalition forces with supplying Kurdish forces arms (Martin, 2018: 97). U.S. supply Kurds in the southern border to fight the war on terror with ISIS in Kobane gave the YPG and PYD international legitimacy and support by superpowers such as the U.S., France, and Russia in counterterrorism efforts thereby strengthening their position in the region. This therefore became an intolerable threat for Turkish foreign policy (Karademir, 2019: 39-41).

Turkey declared that it would do whatever possible to curb Kurds in Syria. On August 24, 2016, to March 29, 2017, Turkey launched "Operation Euphrates Shield" in Northern Syria to establish a "Safe Zone" with the cooperation of its non-state actor allies who are against Kurds and regime of Assad. The Turkish government aims to eliminate the SDF and ISIS up to the west bank of Euphrates. Turkey calls both the SDF and ISIS terrorist organizations that have threatened its national security and must be eliminated. (Martin, 2018: 100-101) At the same time, the Turkish support of the Syrian opposition groups of radical Islamic groups cannot be ignored, which among them, are the two prominent groups, the groups of Syrian al-Qaeda affiliates, Jabhat Fateh al-Sham (Jabhat al- Nusra), and Salafi Ahrar al-Sham. (Stein, 2016)

In March of 2018, President Tayyip Erdoğan invaded the Kurdish area in Syria under the justification of self-defense to eliminate any Kurdish forces or any panKurdish activities. He launched a second military operation under the name of "Operation Olive Branch" on January 21, 2018 and attacked the Kurdish canton of Afrin under the flag of bringing peace to the region (VOA, :22/1/2018). Nearly 200,000 Kurds were displaced from their homeland after the intensive offensive war. Turkey and the U.S. divergent policies regarding these attacks with the U.S. disputing the invasion by Turkey. The Turkish government accused the U.S. of supporting a threat to their national interests. The U.S., in response, emphasized support of the Kurds to eliminate any threat to Turkey and Syria through the common interest of eliminating terror (Barkey, 2019).

On October 9, 2019, after a call between President Trump and President Erdogan, Turkey launched a third operation against the Kurdish SDF in northeastern Syria. "Operation Peace Spring" was launched with the 'justification' of eliminating terrorist groups from the area and situating 2 million refugees in the Kurdish area under the "Safe Zone" project. This led to further Kurdish displacement (CNBC, 2019). 


\section{QALAAI ZANISTSCIENTIFIC JOURNAL \\ A Scientific Quarterly Refereed Journal Issued by Lebanese French University - Erbil, Kurdistan, Iraq \\ Vol. (5), No (3), Summer 2020 \\ ISSN 2518-6566 (Online) - ISSN 2518-6558 (Print)}

\subsection{Russia}

Alongside domestic conflicts and crises, there have been external influences in Syria. Russia is a country that has an extensive historical relationship and influence in Syria. When the minority Alawite group overthrew the majority Sunni rule, the Ba'ath regime became entrenched and then consolidated when Hafez al-Assad took power in 1970. Since then, the relations between Syria and Russia (formerly the U.S.S.R) started. The Soviets considered Syria as an important and strategic ally among the states in the Middle East. Despite differences in ideology, the two countries had bilateral treaties of friendship and cooperation. The current influence of Russia harkens back to the relationship formed with the U.S.S.R when the KGB supplied armaments, military advisors, and naval forces in the Syrian port of Tartus (Allison, 2013: 801-818). When soviet strategic relations declined in the Middle East and the Arab world, Syria remained as a key state in the center of Russia's strategic policy in the region (Malashenko, 2013: 8-9).

\section{Factors behind Russian support the Assad regime:}

After the Arab Spring in Syria, Russia maintained the position of ensuring the survival of the Assad regime and returning territories lost during the war with ISIS to the incumbent Syrian regime. There are several reasons why Russia seeks to protect the Syrian government.

The main reason stems from Russia's desire to protect its sphere of influence in the region. Russian foreign policy, therefore, is opposed to any interference that would lead to regime changes in Syria (Yaphe, 2014: 17). Russia seeks to support the Syrian regime to have international diplomatic importance and maintain its policy in the Middle East as it had during the 1950s and 1960s. President Vladmir Putin seeks to reclaim Russian influence in the Middle East (Russell, 2018). Russia does not wish to see the loss of its last ally in the region. The overthrow of Colonel Muamar Ghaddafi in Libya led to the decline of Russian influence with the Libyan government. It was a serious detriment to Russian ambition in the region when a new pro-western government came into power opposing Russian influence in the region. The strategic policy of Russia supporting the Assad regime is to safeguard its position in the region. Even with its efforts to support the Assad regime, Russia faces additional concerns with the Arab states opposing the Assad regime. Despite international criticism, Russia has not withdrawn from its policy of supporting the current Syrian regime (Malashenko, 2013). 


\section{QALAAI ZANISTSCIENTIFIC JOURNAL \\ A Scientific Quarterly Refereed Journal Issued by Lebanese French University - Erbil, Kurdistan, Iraq \\ Vol. (5), No (3), Summer 2020 \\ ISSN 2518-6566 (Online) - ISSN 2518-6558 (Print)}

Another key reason Russia involves itself in the maintenance of the Assad regime is its previous experience in the bloody Chechen conflict and with radical Islamists. Russia rejects any regime change that could lead to the rise of radical Islamic revolution (Crosston, 2014: 95-101). The core of Russian policy in the region focuses on the prevention of spillover radical Islamist movements and the prevention of regime change, which would diminish Russia's credibility and influence in the region and on the world stage. Therefore, Russia maintains firm position against regime changes and threats to state sovereignty.

Since the Chechnyan conflict in 2003, Russia has designated the Muslim Brotherhood as terrorists. In Syria, Chechens are acting against the Alawite regime (Allison, 2013: 801-818). It is estimated that 9000 people have joined the Salafist Islamist groups of Islamic States, Al-Qaeda, and other radical Islamist groups in Russia, the Caucuses and Central Asia. Russia views this potential spillover as a threat to its own Islamic population (Jones, 2019: 9). Because there are approximately 20 million Russian Muslims, the Russian government takes critical and strategic action to prevent tensions from spilling over into its region. Russia has made concerted efforts to preserve Assad's regime by attempting to mediate a peace process between Assad and opposing forces, inviting Arab officials to attend a Russian-Arab forum, and destroying Assad's chemical weapons (Malashenko, 2013: 10-13). In Geneva, On 14 September 2013, Russia with the United States came to comprise on the destruction of Syrian chemical weapons after the U.S. threatened to launch a strike against Assad for their use on civilians (UNSC, 2013: 1-2).

Even though Syria is militaristically dependent on Russia, Syria also has economic and industrial ties to Russia. The Syrian civil war provided more opportunity for Russia to test its weapons and strengthen its market position and deploy troops and combat aircraft to Khmeimim Airfield in the Syrian province of Latakia. There have been several arms deals and military contracts between both countries. On January 18, 2017, Russia and Syria entered into an agreement "on the expansion and modernization of the Russian naval maintenance facility in the Syrian port of Tartus" (globalsecurity, 2019). Syria granted Russian Warships access to Syrian ports and waters. The expansionism of Russian presence in the region will is solidified through this agreement and allows for Russia to test its military capabilities ${ }^{2}$ (Kuimova, 2019:

${ }^{2}$ Russia claimed that "more than 200 "advanced types of weapons" and military equipment, and several weapon systems demonstrated high performance. These include 


\section{QALAAI ZANISTSCIENTIFIC JOURNAL \\ A Scientific Quarterly Refereed Journal Issued by Lebanese French University - Erbil, Kurdistan, Iraq \\ Vol. (5), No (3), Summer 2020 \\ ISSN 2518-6566 (Online) - ISSN 2518-6558 (Print)}

7-8). Russia views the existing Syrian regime as less chaotic and non-threatening to Russian interests. Russia seeks to legitimately empower its position globally and regionally (Crosston, 2014: 95-101).

At the international level, Russia supports the Assad regime by applying its veto power to any policy or decision against the Syrian government in the UNSCR. When vetoing, Russia cites the threat of instability, chaos, and increased danger from the rise of radical Islamists if Assad is removed (Russell, 2018).

Russia, with its geopolitical ambition, will continue to include Syria as part of its foreign policy in the Middle East. The Russian government makes agreements or negotiates with its rivals to guarantee Assad remains in power. For this reason, the U.S. and Russia must compromise to achieve their priorities in Syria. For the U.S., the elimination of ISIS is the preeminent concern. However, protecting the Assad regime, including from the threat of ISIS, is Russia's primary goal (Duclos, 2019) (Al-Istrabadi, 2018: 182-184).

\subsection{The Processes and Agreements between Turkey and Russia on the Syrian Crisis}

Since 2016, several steps have been taken between Turkey and Russia to reach agreement on the Syrian crisis. On December 12, 2016, Russia, Turkey, and Iran met in Kazakhstan to establish the de-escalation zone in the Syrian city of Idlib. This was, however, ignored once Russia attacked the area (RÜMA, 2019: 77-81). In 2017, the first of two Sochi agreements was reached to establish the 15 to $20 \mathrm{~km}$ "de-militarized zone" in the Idlib territory. However, Russia attacked the Aleppo rebels in retaliation for chemical weapons use on November 24, 2018 (Russell, 2018: 7). The second Sochi agreement reached on October 22, 2019 led to agreement between Russia and Turkey on the Syrian refugee situation in the Kurdish area of northeastern Syria. Additionally, the two countries agreed on eliminating terror, preserving the Syrian state's integrity, and reviving the Adana agreement of 1998 between Syria and Turkey. The agreement came after the Turkey offensive in northeastern of Syria to remove the YPG Kurdish forces. Russia and Turkey reached a compromise on mutual operation in a 30 kilometer by 10 kilometer zone (bloomberg.com, 2019). In the United States' perspective toward Turkey, the establishment of closer relations between Turkey and

Pantsyr air defense systems and the sea-launched Kalibr and air-launched Kh-101 cruise missiles, as well as Russian combat aircraft" (Kuimova, 2019: 7-8) 


\section{QALAAI ZANISTSCIENTIFIC JOURNAL \\ A Scientific Quarterly Refereed Journal Issued by Lebanese French University - Erbil, Kurdistan, Iraq \\ Vol. (5), No (3), Summer 2020 \\ ISSN 2518-6566 (Online) - ISSN 2518-6558 (Print)}

Russia as well as agreements made between them has further complicated the intention of the U.S. to halt Turkish expansion in Syria (CPG, 2019: 19).

\section{Trump Strategy of smart power in Syria}

Trump's administration and Obama's administration may diverge on several points. However, they share a common thread in non-military intervention in Syria. However, Trump's foreign policy is focused on counterterrorism and the curbing of Iranian ambition in Syria, which requires the U.S. to remain involved. Additionally, Kurdish forces remain as significant allies to the U.S. in Syria and this alliance allows for the U.S. to pursue its policy in the region including the protection of Israel. The previous administration had the intention to leave the region after completing its mission in the War on Terror. However, the complexities and number of actors in Syria convolute the situation and any notion of U.S. withdrawal. Therefore, Trump maintains policy decisions to deter adversaries in the country and region.

\subsection{Counterterrorism in Restrained Attack}

Even though the United States' role in Syria after 2011 was that of non-military engagement for imposing regime change, Obama did condemn Assad's harsh action against protestors many times. Prior to the ISIS threat, the United States had not had a specific role in Syria. When ISIS seized large territories in Iraq and Syria in 2014, the U.S. engaged in restrained, limited warfare. The United States needs to provide security and stability to pursue its interests and therefore pursued the war on terror. To maintain this policy in Syria, the U.S. did not seek to combat terrorism by cooperating with, and consequently maintaining, the Assad regime. Instead, the Trump administration relied on other actors in Syria to ensure safety and stability (Ratney, 2018: 54).

The U.S. position in Syria was not significant before 2014, and under the previous administration, U.S. engagement was focused on eliminating terror threats. Under the Trump administration, U.S. engagement was approached using smart power, thereby limiting the need for deep and intensive military engagement. Of particular note, the Trump administration consistently stated that U.S. involvement was limited to counterterrorism efforts and that with the defeat of ISIS " [U.S. presence] in Syria was not open ended and it was never intended to be permanent...". Despite internal disagreements in his administration, Trump has maintained his stance on U.S. withdrawal from Syria (Trump, 2018a). 


\section{QALAAI ZANISTSCIENTIFIC JOURNAL \\ A Scientific Quarterly Refereed Journal Issued by Lebanese French University - Erbil, Kurdistan, Iraq \\ Vol. (5), No (3), Summer 2020 \\ ISSN 2518-6566 (Online) - ISSN 2518-6558 (Print)}

Trump's announcements on his intentions regarding troop withdrawal and U.S. policy in the region have garnered negative international reactions forcing his administration to pursue "damage control" while reiterating the NSS and NDS policies of supporting allies and being a world leader. When Trump ordered the withdrawal of U.S. combat troops from Syria and Afghanistan, the negative reactions from the global community prompted Secretary of State Pompeo to visit the region, especially the Gulf States (Trump, 2018b). In his speech in Cairo on January 10, 2019, Secretary Pompeo reiterated combat withdrawal from Syria does not alter U.S. Strategy in fighting the War on Terror nor does it indicate the U.S. would be leaving the region (Pompeo, 2019c).

The Trump administration announced the end of ISIS. On the eve of this announcement, Trump developed withdrawal plans from areas where conflict had ended, and ISIS had been defeated. However, the occasional attacks of ISIS in some of these areas indicated that even if not physically strong, ISIS ideology, and consequently the threat of ISIS, still existed. Trump highlighted the death of AI Baghdadi, the leader of ISIS, as a success for the United States to bolster positive public opinion towards his administration.

"The United States has been searching for Baghdadi for many years. Capturing or killing Baghdadi has been the top national security priority of my administration...Baghdadi has been on the run for many years, long before I took office. But at my direction, as Commander-in-Chief of the United States, we obliterated his caliphate, 100 percent, in March of this year" (Trump, 2019b).

Trump has highlighted this success extensively as a win accomplished using limited military engagement with very limited casualties as compared to the Bush administration's campaigns in the region.

Despite the Trump administration announcing the end of ISIS, the U.S. still allocated a specified budget for counterterrorism in the National Defense Authorization Act in FY2019 for US engagement in Syria. The amount of funding, however, has declined. In December 20, 2019, Trump signed the National Defense Authorization Act for FY2020. The amount of requested previously dropped from $\$ 745$ million to $\$ 545$ million for the Counter-Islamic State of Iraq and the Levant CISIL) Train and Equip Fund (CTEF). The budget includes $\$ 200$ million approved for "decreased program" and "Transfer to DSCA ${ }^{3}$ Security Cooperation." The Syrian CTEF

${ }^{3}$ Defense Security Cooperation Agency 


\section{QALAAI ZANISTSCIENTIFIC JOURNAL \\ A Scientific Quarterly Refereed Journal Issued by Lebanese French University - Erbil, Kurdistan, Iraq \\ Vol. (5), No (3), Summer 2020 \\ ISSN 2518-6566 (Online) - ISSN 2518-6558 (Print)}

program was reduced from $\$ 500$ million to $\$ 300$ million in AY2019. CTEF specific requirements for both Syria and Iraq dropped from the total request of $\$ 1,045,000,000$ to $\$ 845$ million (CPG, 2019: 3406) (NDAA FY2020, 2019: 5-14) . Between FY2019 and FY2020, the previous $\$ 850$ million budget decreased to $\$ 545$ million (CPG, 2019: 3406). While the U.S. spent \$9.1 million on humanitarian assistance, Operation Inherent Resolve (OIR) in counter-ISIS in Iraq and Syria ballooned to approximately $\$ 28.5$ billion by September 2018 (CRS, 2019).

The United States does not intend to participate in humanitarian assistance for Syria so long as the Assad regime is in control and under the patronage of Russia and Iran. In 2017, The UN envoy estimated that Syrian reconstruction would need \$250 billion. That number ballooned to $\$ 388$ billion in August 2018 due to damage incurred from the conflict. The United States does not seek to fund an area under the control of an adversarial regime before political settlement is reached. The U.S. Congress passed the No Assistance for Assad Act (H.R.1706) to prevent "directly or indirectly" funding the areas under the Assad regime until all conditions put forth by the U.S. are met $^{4}$ (ibid:8-9). In contrast, the U.S. has spent more than $\$ 2.5$ billion on humanitarian assistance for Iraq since 2014. (Blanchard, 2019)

\subsection{Support Kurdish Forces}

The United States has been considered a global leader since the end of World War II. However, U.S. troop withdrawal from Syria in October 2019 led to a vacuum that would be filled by Turkey. The ISIS threat in Syria was considered vital to U.S. national interests and the international community. The U.S. engaged in Syria initially by supporting Islamic groups in opposition to the Assad regime, but then pivoted that support to the SDF and YPG Kurdish forces. When ISIS was defeated and Trump ordered the U.S. withdrawal from Syria, a void was left that could be filled by opposition forces in the larger Syrian conflict, leaving the previously supported SDF and YPG vulnerable. The U.S. had accomplished its mission to defeat ISIS and the

4 “ceasing airstrikes against civilians, releasing all political prisoners, allowing regular access to humanitarian assistance, fulfilling obligations under the Chemical Weapons Convention, permitting the safe and voluntary return of displaced persons, taking steps to establishing meaningful accountability for perpetrators of war crimes, and halting the development and deployment of ballistic and cruise missiles." (CRS, 2019) 


\section{QALAAI ZANISTSCIENTIFIC JOURNAL \\ A Scientific Quarterly Refereed Journal Issued by Lebanese French University - Erbil, Kurdistan, Iraq \\ Vol. (5), No (3), Summer 2020 \\ ISSN 2518-6566 (Online) - ISSN 2518-6558 (Print)}

President Trump made it clear that the U.S. has no reason to further support the Kurdish forces against Turkey.

"After defeating 100\% of the ISIS Caliphate, I largely moved our troops out of Syria. Let Syria and Assad protect the Kurds and fight Turkey for their own land. I said to my Generals, why should we be fighting for Syria........ and Assad to protect the land of our enemy? Anyone who wants to assist Syria in protecting the Kurds is good with me, whether it is Russia, China, or Napoleon Bonaparte. I hope they all do great; we are 7,000 miles away!" (Trump, 2019c)

Donald Trump later altered the plan of full withdrawal totally and 500 U.S. troops remained in the oil fields. This shift in his own policy came after domestic pressure noted the anti-American value (abandoning allies) associated with the decision, the lingering presence of ISIS, if even only ideologically, and the need to protect oil fields (Ward, 2019).

At the time of this writing, more than 600 U.S. troops remained in Syria, after the large scale of criticism of Trump's decision on U.S. troop withdrawal (Frantzman, 2019). Much of Trump's rhetoric can be contradictory unto itself. On one hand, Trump essentially states that the mission is done, and it is not a U.S. concern to protect the Kurds in Syria. On the other hand, domestic pressure and criticism from officials and members of his own party swayed his decision and he altered his rhetoric to remain, protect the oil fields, and support the Kurds. Trump says that Kurds can protect the oil fields with U.S. troops and utilize the resource as a source of income. During Trump's visit to celebrate thanksgivings with U.S. troops in Afghanistan on November 28,2019 , he reiterated his stance of protecting the oil fields in Syria and helping the Kurds. Trump said that withdrawal began "because it [Syria] is secure, but we didn't leave totally we kept the oil...and we can help the Kurds... we got the wealth and we got the money" (Trump, 2019d). He further discussed his stance during George W. Bush's administration saying that when he was civilian "they didn't listen to [him] when I have been saying for a long time keep the oil Keep the oil" but now "they have to" (ibid).

Seventy percent of oil fields and facilities in Syria are SDF controlled even after the Turkish offensive and Kurdish loss of territory. This is significant as evidence by ISIS profiting over $\$ 40$ million dollars from oil each month after gaining control of Der al Zur in 2015. However, after U.S. strikes, oil facilities were heavily damaged and need to be rebuilt. The oil reserves in the province of Der al Zur are estimated to be approximately 2.5 billion barrels located in the east of Syria near the Iraqi border and 


\section{QALAAI ZANISTSCIENTIFIC JOURNAL \\ A Scientific Quarterly Refereed Journal Issued by Lebanese French University - Erbil, Kurdistan, Iraq \\ Vol. (5), No (3), Summer 2020 \\ ISSN 2518-6566 (Online) - ISSN 2518-6558 (Print)}

Hassakeh in the northeast of Syria. In 2008 the oil production was 406,000 (bpd) but dropped to $353.000 \mathrm{bpd}$ in 2011 and again in 2018 to $24.000 \mathrm{bpd}$. Nearly 90\% of production was lost after 2011. Syria entered into an agreement in 2018 with Russia to rebuild the oil and gas infrastructure. However, U.S. control of the oil fields through the SDF and the difficulty of gaining access to the area has prevented Russia from enacting the agreement. This is one factor influencing the Trump administration's decision stay in Syria. Even though the United States produces oil, control of the oil fields in Syria gives the U.S. and Kurds a source of income for spending on the war on terror (Reality check team, 2019). This further strengthens efforts to undermine Iran as mentioned in the U.S. National Defense Authorization Act for FY2020, "the degree to which efforts of the United States to sustain and strengthen Kurdish forces in Syria may undermine the influence of Iran and Iranian-backed forces in Syria;' (NDAA FY2020, 2019: 2242) .

\subsection{Political Solution}

The United States has not taken any direct action toward regime change in Syria. Early in the civil war the United States said Bashar al-Assad should step back from power, but we see that later the U.S. changed the strategy to negotiation. The Trump administration, focusing involvement in Syria towards the removal of ISIS and curbing Iran, prefers the participation of the Syrian people to determine their future. The U.S. announced that it will not participate in Syrian reconstruction under Assad rule, and there must be political settlement in Syria. This settlement under the UNSCR $2254^{5}(2015)$ and the Geneva communique 2012 with the Constitutional draft must be implemented otherwise the U.S. will not participate in Syrian post-conflict

${ }^{5}$ The UNSC Resolution 2254 on December 18, 2015, was issued for a political solution. And regarding the Geneva Communiqué of June 30, 2012, to find a political solution. And, as mentioned in Resolution 2118(2013) to establish the transitional governing body by which it contains the executive power. In any of the resolutions regards Syria, reiterated preserving the Integrity, sovereignty, unity, independence of the Syrian Arab Republic. The resolution 2254, emphasizes the role of women in government, and human rights. This must be implemented through the participation of all Syrian people. They must have their negotiation representatives in drafting the constitution. And the government must be democratic and pluralistic which guarantees minorities rights. The process of a ceasefire must be implemented ${ }^{5}$. (UNSC, 2015b) 


\section{QALAAI ZANISTSCIENTIFIC JOURNAL}

A Scientific Quarterly Refereed Journal Issued by Lebanese French University - Erbil, Kurdistan, Iraq

Vol. (5), No (3), Summer 2020

ISSN 2518-6566 (Online) - ISSN 2518-6558 (Print)

reconstruction. ${ }^{6}$ It will allocate funding in the process of equipping and training the U.S. backed group anti-terror organization (CRS, 2019).

With regards to response to the atrocities of Bashar al-Assad, on December 20, 2019, the Trump administration released the "Caesar Syria Civilian Protection Act of 2019".

"The law provides for sanctions and travel restrictions on those who provide support to members of the Assad regime, in addition to Syrian and international enablers who have been responsible for, or complicit in serious human rights abuses in Syria. The law also seeks to deny the Assad regime the financial resources used to fuel his campaign of violence and destruction that has killed hundreds of thousands of civilians. The Caesar Act sends a clear signal that no external actor should enter into business with or otherwise enrich such a regime." (Pompeo, 2019d)

The Trump administration emphasizes political settlement must be implemented and supports the UNSCR 2254 for this purpose. Further to this point, the U.S. supports the implementation of a constitution committee for Syria where freedom, liberty, democracy with a free election, and voting enfranchisement for all must be guaranteed. To consolidate the implementation of UNSCR 2254 for a political solution in Syria a "Small Group" 7 of eight countries, among them the United States, reiterated the necessity of finding a political solution to the Syrian crisis. The joint statement of this group was to end all atrocities by the regime and supported the establishment of the Constitution committee for drafting a new constitution. This statement also mentions the process of returning refugees and IDPs: "Any attempts at deliberate demographic change cannot be acceptable." This is in direct response to the Turkish attempt to bring Syrian refugees to north Syria in what Turkey calls a Safe Zone that, in reality, displaced Kurdish civilians (U.S.Embassy in Syria, 2019).

According to the constitutional committee "The United States continues to support the UN Secretary-General, Antonio Guterres, and the UN Special Envoy for Syria, Geir Pedersen, in their efforts to facilitate the work of the Syria Constitutional

6 "America will never have good relations with Bashar al Assad," the Syrian people ultimately "get to decide who will lead them and what kind of a government they will have. We are not committed to any kind of regime change." (CRS, 2019)

7 Small groups are including "Foreign Ministers of Egypt, France, Germany, Jordan, the Kingdom of Saudi Arabia, the United Kingdom, and the United States of America" which are included as Small Group to lasting the UNSCR 2254. 


\section{QALAAI ZANISTSCIENTIFIC JOURNAL \\ A Scientific Quarterly Refereed Journal Issued by Lebanese French University - Erbil, Kurdistan, Iraq \\ Vol. (5), No (3), Summer 2020 \\ ISSN 2518-6566 (Online) - ISSN 2518-6558 (Print)}

Committee. This past week, the drafting committees had the second round of meetings which were meant to move the process forward of drafting a constitution that reflects the will of the entirety of the Syrian people." (Ortagus, 2019)

However, other players, such as Turkey and Russia, in Syria complicate the situation and will force the Trump administration to seek concessions with them. The process of political solution despite the presence of domestic conflicts between regional and international players is the primary factor for the future of Syria.

As previously mentioned, Turkey has developed closer relations with Russia. This concerns the U.S. The reason for this fear is Turkey's successful relationship with Russia to apply pressure on the U.S. and EU by preventing them from supplying Kurdish forces in Syria with weapons. Second, Turkish and Russian influence in the region is against U.S. interests. Finally, the presence of radical Islamists and solidification of Assad legitimacy through Turkish and Russian support. Turkish concern also lies in the Syrian Kurds influencing Turkish Kurds through the establishment of Kurdish regional entities in Syria. It is beneficial for Russia to bring Turkey to the table to reduce its efforts of anti-regime. Russia leverages Turkish concerns about Kurdish expansion against the U.S. and western countries. Russia plays the role of a decisive balance between the major government players. The presence of NATO additionally has an impact on Turkish foreign policy in the ME. Turkish relations from the geopolitical conflict shifted to cooperation and rapprochement in Syria. This kind of relationship is based on the process than the ultimate result (RÜMA, 2019: 81-84).

Turkish influence in the region, especially in Syria, after US withdrawal from Iraq increased and it is continuing to try to fill the vacuum. Russia and Iran are also attempting to increase their sphere of influence in the region to pursue their policies in the absence of the United States (KARADEMIR, 2019: 37). Despite of many agreements between Turkey and Russia over the Syrian crisis, there are no tangible results because Russia and Turkey clashed multiple times over Idlib, violating the very agreements they made. Furthermore, the Trump administration does not intend to engage militarily in Syria only seeking to remain in controlled areas to isolate Iranian influences in the region. Rather the U.S. pursues the stance of international cooperation to arrive at a solution to the Syrian crisis.

\subsection{Protecting Israel}

Israel concerned Iran as threat after U.S. withdrawal from Iraq and the region since 2011. Following uprising in Syria, the situation deteriorated in Israel, when it observed 


\section{QALAAI ZANISTSCIENTIFIC JOURNAL \\ A Scientific Quarterly Refereed Journal Issued by Lebanese French University - Erbil, Kurdistan, Iraq \\ Vol. (5), No (3), Summer 2020 \\ ISSN 2518-6566 (Online) - ISSN 2518-6558 (Print)}

the Iranian military activity in Iran, when Iran expanded its influences in Iraq, and, from there, into Syria. Iran has a military base with the support of Russia. Israel monitors Iranian action and its ambition in Syria as Iran supports Lebanese Hezbollah, supplying them with missiles and rockets. Hezbollah, who are the Iranian proxy in Syria, are fighting for Assad's survival. They have 3000 fighters in Syria who fight with the Iranian military of IRGC-QF. This concerns the United States because threat of Hezbollah and Hamas with the support of Russia and Iran against Israel is in direct conflict with U.S. support of Israel. Consequently, the U.S. must act to curb Iranian influence. This, however, must be done through U.S. relations with Russia and pressure on Moscow to also curb Iran in Syria. Hezbollah owns advance weapons, cyber capabilities and military capabilities that can threaten Israeli targets. Israel is aware of this threat and started bombing the Iranian military bases, most notably the T-4 airbase in the eastern part of the Homs governorate which is 100 miles away from Damascus. Russia let Israel target the Iranian base, but also criticized Israel publicly in July 2019 for intervening and violating Syrian sovereignty (NDAA FY2020, 2019: 6). The Trump administration heavily weighs the Israeli concerns over Iranian influences in the region and Syria due to the long-established strategic relationship between the U.S. and Israel. The U.S. supports Israel because of common threats of terror, the threat of nuclear proliferation in the region, cyber warfare, and the threat of Islamist radicals. Their partnership and cooperation in advancing military technology ensures mutual benefit. Israel with strong U.S. support of security assistance and bilateral cooperation in the Middle East has become a strong deterrent in the region. Consequently, Israel is a focal point for the United States to deter any threat. Israel is the only stable and democratic country in the Middle East, which is a region that for many decades was engulfed in conflicts and instability (Global Policy Forum, 2006: 1931). Any threats in the region to Israel's national security could undermine U.S. interests in the region. They have a strategic partnership and preserving Israeli security is one of the U.S. fundamental interests in the Middle East. Regardless of threats in Iraq and Syria, the presence of Iran and its proxies could threaten Israel. This threat has heightened due to the strengthening of Iranian influences in both Iraq and Syria.

Despite Trump's efforts to cut the hand of Iranians in Syria and Iraq, the dissolution of the previous deal with Iran, and many steps of in favor of Israel such as relocating its embassy to Jerusalem and recognizing Jerusalem as the Israeli capital, the Iranian 


\section{QALAAI ZANISTSCIENTIFIC JOURNAL \\ A Scientific Quarterly Refereed Journal Issued by Lebanese French University - Erbil, Kurdistan, Iraq \\ Vol. (5), No (3), Summer 2020 \\ ISSN 2518-6566 (Online) - ISSN 2518-6558 (Print)}

threat remains. Trump has utilized the steps as tools to support and defend Israel from future threats (Taylor, 2019).

\subsection{Curbing Iranian role}

The United States under the Trump administration, after the breakdown of the JCPOA, imposed "maximum pressure" on Iran through more economic sanctions. Yet after two years, according to the Trump administration, such sanctions have not stopped the Iranian development of its missile programs, cyber-attacks, and military technology advancement. For this reason, Trump has taken "measured offensive action" deterring Iranian with striking its targets and its interests. It would not make sense, in the U.S. perspective, if the U.S. waits until Iran attacks its interests in the region (Seth G. Jone at el, 2019: 10). The United States has taken "decisive defensive action" but at the same time, will not wait to be attacked by Iran and its proxies. The U.S. with its allies and local and regional powers will deter Iranian ambition to halt its further destructive plots in the region. This is demonstrated clearly with the targeting of Iranian bases and affiliates in Iraq and Syria (U.S. Department of Defense, 2020). For example, the U.S. targeted five Hezbollah bases in Iraq and Syria on December 29, 2019 in response to the Katiab Hezbollah attack on the U.S. base in Kirkuk on December 27, 2019, which killed a U.S. contractor and other personnel (Anderson, 2020).

The Trump administration killing of Qasim Soleimani was, as Thomas Schelling states, "Latent violence" 8 to deter Iran (Schelling, 2008: 3) through punishment and pressure Iran not to take steps up the "escalatory ladder" (Seth G. Jone at el, 2019: 10).

With killing Qasim Suleimani touted as a success by the Trump administration, Mark Esper in his interview with CNN on January 12, 2020, said that the U.S. is safer today because, Qasim Suleimani was killed, the U.S. deterred Iran without U.S. casualties, and the U.S. ensured its friends and allies in the region that the United States will stand up to defend our interests in the region (Esper, 2020). Trump has additionally asked NATO to expand its role in the Middle East in deterring Iran:

8 "It is the threat of damage, or of more damage to come, that can make someone yield or comply. It is latent violence that can influence someone's choice-violence that can still be withheld or inflicted, or that a victim believes can be withheld or inflicted. The threat of pain tries to structure someone's motives, while brute force tries to overcome his strength" (Schelling, 2008: 3) 


\section{QALAAI ZANISTSCIENTIFIC JOURNAL}

A Scientific Quarterly Refereed Journal Issued by Lebanese French University - Erbil, Kurdistan, Iraq

Vol. (5), No (3), Summer 2020

ISSN 2518-6566 (Online) - ISSN 2518-6558 (Print)

"Today, I am going to ask NATO to become much more involved in the Middle East process." (Trump, 2020a) This is what Trump asks other powers to participate in isolating Iran, like what of transactional policy which he believes is unfair to counter such a threat alone.

The use of smart power, combining soft and hard power, could weaken Iranian influences in Iraq and Syria. Tension has increased, but the Trump administration will not seek a regime change in Iran as a priority. Despite calling Iran evil and destructive toward its own nation and in region, Trump seeks to change Iran's behavior, halt its nuclear program, and reduce its influence in the region (Seth G. Jone at el, 2019: 10). "We do not seek regime change. However, the Iranian regime's aggression in the region, including the use of proxy fighters to destabilize its neighbors, must end, and it must end now." (Trump, 2020b)

The Trump administration calls upon the Iranian regime to behave like a "normal country" without a nuclear program, without a ballistic missiles program, without employing hostage-taking, and without the use of proxies in the region in the region (Esper, 2020). The message behind U.S. rhetoric is to diminish the Iranian role in the region through soft power and diplomacy instead of military intervention. However, if Iran were to give in to these pressures, it would be vulnerable to ruin and collapse. This concerns Iran as it does not wish to end up like Libya and Iraq. However, if Iran continues to threaten U.S. interests in the region, Trump will target Iranian strategic bases in Iran.

Both Russia and the U.S., despite differences in their strategy and policies, have common interests with regards to Iran including the desire to prevent nuclear ambitions in Iran and Iranian hegemony in the Middle East. The Trump administration has attempted to get concession with Russia, accepting them as a regional player, especially in Syria, in exchange for curbing Iranian role in Syria. Furthermore, Russia has developed relations with countries that are against Iranian policies like Israel, Egypt, Saudi Arabia, and Turkey. This has led to more concessions with the United States on the Iranian issue in the region (Graham, 2019). John Bolton in his book, the room where it happened mentioned about Putin aim regard Iran, "Putin pointed at me (Bolton) and said I should tell Trump directly that the Russians didn't need Iranians in Syria, and that there was no advantage for Russia in having them there. Iran was pursuing its own agenda, given their goals in Lebanon and with the Shia, that had nothing to do with Russian goals, and was creating problems for them and Assad. Russia's goal, said Putin, was to consolidate the Syrian state to 
prevent chaos like in Afghanistan, whereas Iran had broader goals." (Bolton, 2020: 120)

\section{Conclusion}

The U.S. communicates its global policy to the international stage through the doctrines of its presidents. In this research paper, we could demonstrate the Trump doctrine and its impact on U.S. foreign policy toward Syria. We could reach to the solution for the question of our research through colleting our data and analyzing them in order to approve our hypothesis. The Trump doctrine is under the business influence of the Transactional realist approach, pursue the U.S. national and security interests in Syria. For many decades the United States has been involved in the Middle East under different administrations. Moreover, the foreign policy of the United States covered by many perspectives and concepts toward the world would make the world safer to achieve the U.S. national interest. Today, the United States, under the Trump administration, cannot withdraw totally in world affairs; however, Trump works hard to isolate America from many world affairs, which he thinks does not U.S. concerns. Furthermore, he seeks to prevent from more losing U.S. lives and money in the world. His policy is to impose allies and adversaries to take some of U.S. burden, in War on Terror, and pursuing global security.

Furthermore, he thinks the world was unfair to the United States, and the previous administration has taken the wrong policy toward the world, particularly the Middle East. Moreover, the deep engagement was wrong. However, the worth than that was the U.S. withdrawal from Iraq in 2011. His general doctrine holds the bargaining methods, all his rhetoric and speech and tweets identify his transactional realist approach. However, through this paper, we could see what his rhetoric is and what he intends to do, is distinguished from what the long term strategy of the U.S. is. The long or grand of U.S. strategy is something that Trump cannot withdraw from it. Like the War on Terror, preventing emerging any hegemonic power in the world and curbing Iranian role as long as to protect Israel from any threat in the region. Today, after the many decades of involvement and spending budget for the military in the world, the United States pursues a critical role in drawing the world's political, social, and economic map.

Regardless of what Trump doctrine seeks to pursue, but there are some other factors inside U.S. which make pressure on him to withdraw from some of his decisions which will make the negative consequences on U.S. national and security 


\section{QALAAI ZANISTSCIENTIFIC JOURNAL \\ A Scientific Quarterly Refereed Journal Issued by Lebanese French University - Erbil, Kurdistan, Iraq \\ Vol. (5), No (3), Summer 2020 \\ ISSN 2518-6566 (Online) - ISSN 2518-6558 (Print)}

interest. When Trump ordered the U.S. withdrawal from Syria, after the domestic and external pressure, he stayed in Syria under the name of protecting the oil fields and safe Kurds. However, at the same time, he neither wants to lose the U.S. -Turkish strategic relations nor wants to leave Kurds. He makes a balance between Turkey and Kurdish forces that fought ISIS along with the U.S. coalition forces. In his strategy, he needs both factors in the region to pursue the U.S. foreign policy.

In general, his business rhetoric is a short-term strategy to achieve U.S. interests through bargaining. However, the United States cannot adopt pure isolationist tendencies and must engage with the international community to achieve U.S. interests in Syria through cooperation with other actors in Syria. Trump neither militarily engages Syria fully nor withdraws entirely to prevent the presence of a vacuum that adversaries could fill. Trump will continue to pursue limited military engagement in cooperation with other actors to achieve counterterrorism interests. Despite Trump's self-proclaimed victory over terrorism by killing Abubaker Baghdadi in Syria, 600 U.S. troops remain in Syria to continue fighting in the war on terror and curb Iranian influence in Iraq and Syria to protect Israel. The Trump administration acts to counter any threats to its interests and allies in the region. Keeping a source of oil in Syria guarantees financial resources to support the war on terror and prevent Iran, Turkey, and Russia from gaining any significant advantages. By supporting Kurdish forces while also seeking concessions with Turkey and Russia, the U.S. maintains its smart power policy with limited direct engagement. Trump's actions are ultimately his attempt at restoring what he believes is American "Greatness" that was lost due to previous administrations' deep engagement in the region.

\section{References;}

Abbas, M. (2020) "Palestinians angrily reject Trump Mideast peace plan", 28Jan, [Online], Available: https://apnews.com/0dcb0179faf41e1870f35838058f4d18.

Al-Istrabadi, F. (2018) '" Regional constraints on the U.S. confrontation of ISIS"', in Feisal alIstrabadi, S.G. (ed.) "The future of ISIS: Regional and International implications" , Brookings Institution press.

Allison, R. (2013) '" Russia and Syria: explaining alignment with a regime in crisis"', International Affairs (Royal Institute of International Affairs 1944-), vol. 89, no. 4, Jul. 


\section{QALAAI ZANISTSCIENTIFIC JOURNAL \\ A Scientific Quarterly Refereed Journal Issued by Lebanese French University - Erbil, Kurdistan, Iraq \\ Vol. (5), No (3), Summer 2020 \\ ISSN 2518-6566 (Online) - ISSN 2518-6558 (Print)}

Anderson, S.R. (2020) "The Law and Consequences of the Recent Airstrikes in Iraq", 1Jan, [Online], Available: https://www.lawfareblog.com/law-and-consequences-recent-airstrikesiraq.

Barkey, H. (2019) "The Kurdish Awakening: unity, betraya, and the future of the Middle East", Apr, [Online], Available: https://www.foreignaffairs.com/articles/turkey/2019-02$\underline{12 / \text { kurdish- }}$

awakening?utm campaign=reg conf email\&utm medium=newsletters\&utm source=fa re gistration.

Blanchard, C.M. (2019) '"Iraq and U.S. Policy "', Congressional Research service, no. 18, Oct, Available: IF10404.

bloomberg.com (2019) "Putin, Erdogan Strike Deal on Joint Patrols of Syria Border", 22Oct, [Online], Available: https://www.bloomberg.com/news/articles/2019-10-22/putin-smeeting-with-erdogan-may-decide-fate-of-syria-s-kurds.

Bolton, J. (2020) "The room where it happened", New York: Simon \& Shuster.

Branett, M.N. (2018) ' "What is international relations teory good for? ', in "Chaos in the liberal order: The Trump presidency and international relations polictic, in the twenty- first century" , Columbia University press.

Buckley, C.A. (2012) '"Learning from Libya, Acting in Syria"', Journal of Strategic Security, vol. 5, no. 20.

CNBC (2019) "Three charts that show why Trump thinks NATO is a bad deal", 3Dec, [Online], Available: https://www.cnbc.com/2019/12/03/three-charts-that-show-why-trump-thinksnato-is-a-bad-deal.html.

CNBC (2019) "Turkey launches military operation against Kurds in northern Syria", 90ct, [Online], Available: https://www.cnbc.com/2019/10/09/turkish-president-erdoganconfirms-military-operation-in-northern-syria-has-begun.html [9 Oct 2019].

Colucci, L. (2012) "Tthe natinal security doctrines of the American presidency: how they shape our present and future" , PRAEGER of ABC-CLIO,LLC.

CPG (2019) '"Eurasia's Geopolitical Outlook for 2019:A review-based assessment forEurope and Asia"', German-southest Asian Center of Excellency fo publich policis and Good govenance $C P G$, Jul.

Crosston, M.D. (2014) '"Cold War and Ayatollah Residues: Syria as a Chessboard for Russia, Iran, and the United"', Strategic Studies Quarterly, vol. 8, no. 4, pp. 94-111. 


\section{QALAAI ZANISTSCIENTIFIC JOURNAL \\ A Scientific Quarterly Refereed Journal Issued by Lebanese French University - Erbil, Kurdistan, Iraq \\ Vol. (5), No (3), Summer 2020 \\ ISSN 2518-6566 (Online) - ISSN 2518-6558 (Print)}

CRS (2019) '"Armed Conflict in Syria:Overview and U.S. Response "', Congressional Research Service, Mar, Available: RL33487.

Davis, R. (2015) '" Syria's refugee crisis"', Great Decisions, pp. 65-76.

Duclos, M. (2019) "Assad's Thinking: How Did Syria Get Here, and Where Does the Regime Want to Go Now?", 21Jun, [Online], Available: https://www.washingtoninstitute.org/policyanalysis/view/assads-thinking-how-did-syria-get-here-and-where-does-the-regime-want-to-

go.

Esper, M. (2020) "President Trump saying the US had intelligence that Iran was planning to attack four US embassies.", 12Jan, [Online], Available: https://www.youtube.com/watch?v=xkO4CVOg4qk.

Frantzman, S.J. (2019) "Pence in Kurdistan region and US base in Iraq for surprise visit", 23Nov, [Online], Available: https://www.jpost.com/Breaking-News/Mike-Pence-visits-US-troops-inIraq-to-meet-prime-minister-

608769?fbclid=IwAR19xP4mR2ILwEi8vas5JQGIZRdE8L UNyjcJbzj f FJdBJKDvFQbgrHh0.

Global Policy Forum (2006) "Iraq's Government", [Online], Available: https://www.globalpolicy.org/political-issues-in-iraq/iraqs-government-.html [10 Apr 2019]. globalsecurity (2019) "Russian Naval Base at Tartus / Tartous", [Online], Available: https://www.globalsecurity.org/military/world/syria/tartous.htm [8 Sep 2019].

Graham, T. (2019) "Let Russia Be Russia:The Case for a More Pragmatic Approach to Moscow", Nov/Dec, [Online], Available: https://www.foreignaffairs.com/articles/russia-fsu/2019-1015/let-russia-be-

russia?utm medium=social\&utm campaign=tw daily soc\&utm source=twitter posts.

Grieco, K.A. (2018) '"The 2018 National Defense Strategy; continuity and competition" ', Strategic studies Quarterly, vol. 12, no. 2, pp. 3-8.

HRW (2019) "Syria:events of 2018", [Online], Available: https://www.hrw.org/worldreport/2019/country-chapters/syria\#909488 [20 Aug 2019].

IDMC (2018) Internal Displacement moniter centre, 1-12, [Online], Available: http://www.internal-displacement.org/countries/syria [20 Aug 2019].

Jeffrey Martini et al, (2013) '"Syria as an Arena of Strategic Competition"', in Jeffrey Martini, E.Y.a.W.Y. "Syria as an Arena of Strategic Competition", RAND Corporation.

Jones, S.G. (2019) '" Dangerous Liaisons:Russian Cooperation with Iranian in Syria"', CISIS $B R I E F S$, Jul. 


\section{QALAAI ZANISTSCIENTIFIC JOURNAL \\ A Scientific Quarterly Refereed Journal Issued by Lebanese French University - Erbil, Kurdistan, Iraq \\ Vol. (5), No (3), Summer 2020 \\ ISSN 2518-6566 (Online) - ISSN 2518-6558 (Print)}

Karademir, B.S. (2019) '"A Dance of Entanglement"', Uluslararası ilişkiler / International Relations, vol. 16, no. 62.

KARADEMIR, B.S. (2019) '"A Dance of Entanglement"', Uluslararası Ilişkiler / International Relations, vol. 16, no. 62.

KNC "about KNC", [Online], Available: http://knc-geneva.org/?page id=49\&lang=en [7 Sep 2019].

Kuimova, A. (2019) '"RUSSIA'S ARMS EXPORTS TO THE MENAREGION: TRENDS AND DRIVERS"', euromesco, policy Brief, no. 95, Apr.

Larres, K. (2017) "Donald Trump and America's Grand Strategy: : U.S. foreign toward Europe, Russia and China", may, [Online], Available: https://archive.transatlanticrelations.org/wpcontent/uploads/2017/05/Larres-Donald-Trump-and-America\%E2\%80\%99s-Grand-StrategyU.S.-foreign-policy-toward-Europe-Russia-and-China-Global-Policy-May-2017.pdf.

Malashenko, A. (2013) '"Russia and the Arab Spring"', Carinegie Moscow Center, Oct.

Martin, K.W. (2018) '"Syria and Iraq ISIS and other actors in historical context" ', in Feisal alIstrabad, S.G. "The future of ISIS: Regional and international implication", Brookings Institution press.

Michael, J.H. (2011) '" Dysfunctinal doctrines? Eisenhower, Carter and U.S. military Intervention in the Middle East"', Political Science Quarterly, vol. 126, no. 3, pp. 465-495. NDAA FY2020 (2019) "NATIONAL DEFENSE AUTHORIZATION ACT FOR FISCAL YEAR 2020 ", Dec, [Online], Available: https://docs.house.gov/billsthisweek/20191209/CRPT116hrpt333.pdf.

Nye, J.J. (2019) '"The rise and fall of American hegemony from Wilson to Trump"', international affairs.

Ortagus, M. (2019) "On the Syrian Constitutional Committee in Geneva", 30Nov, [Online], Available: https://www.state.gov/on-the-syrian-constitutional-committee-in-geneva/.

O'Toole, M. (2016) Foreign policy, 22Mar, [Online], Available: https://foreignpolicy.com/2016/03/22/aipac-condemns-donald-trump-speech-we-takegreat-offense/.

Pompeo, M. (2019a) @SecPompeo, 7Jan, [Online], Available: https://twitter.com/SecPompeo/status/1082419194895962112.

Pompeo, M. (2019b) "Secretary Pompeo News Conference", 18Nov, [Online], Available: https://www.c-span.org/video/?466577-1/secretary-state-pompeo-announces-policychange-israeli-settlements. 


\section{QALAAI ZANISTSCIENTIFIC JOURNAL}

A Scientific Quarterly Refereed Journal Issued by Lebanese French University - Erbil, Kurdistan, Iraq

Vol. (5), No (3), Summer 2020

ISSN 2518-6566 (Online) - ISSN 2518-6558 (Print)

Pompeo, M. (2019c) "American troops are coming home from Syria, but this isn't a change of mission. We remain committed to the complete dismantling of the ISIS threat and the ongoing fight against radical Islamist terror. We are looking to our partners to do more going fo ", 10Jan, [Online], Available: https://twitter.com/SecPompeo/status/1083408748159283201. Pompeo, M. (2019c) "U.S. Intent To Withdraw from the INF Treaty February 2, 2019", 2Feb, [Online], Available: https://www.state.gov/secretary/remarks/2019/02/288722.htm.

Pompeo, M.R. (2019d) "Passage of the Caesar Syria Civilian Protection Act of 2019", 20Dec, [Online], Available: https://sy.usembassy.gov/passage-of-the-caesar-syria-civilianprotection-act-of-2019/.

Ratney, M. (2018) '" Post conflict stabilization: what can we learn from Syria?"', PRISM, vol. 7, no. 4.

Reality check team (2019) "Syria war: Who benefits from its oil production?", 21Nov, [Online], Available: https://www.bbc.com/news/50464561.

RÜMA, I. (2019) '"Russian and Turkish Foreign Policy Activism in the Syrian Theater"', Uluslararası iliş̧kiler / International Relations, vol. 16, no. 62.

Russell, M. (2018) "Russia in the Middle East:From sidelines to centre stage", Nov, [Online], Available:

https://www.europarl.europa.eu/RegData/etudes/BRIE/2018/630293/EPRS BRI(2018)6302 93 EN.pdf [25 Aug 2019].

Sach, J.D. (2018) '"The Trump 's New National Security Strategy"', in "A new Foreign policy': Beyond American Exceptionalism", Columbia University Press.

Schelling, T.C. (2008) "Arms and influence", NEW HAVEN AND LONDON and YALE UNIVERSITY PRESS.

Schøtt, A.S. (2017) '"From the Forgotten People to World-Stage Actors:THE KURDS OF SYRIA"', Danish Defence, Jun.

Seth G. Jone at el (2019) '"Iran's Threat to Saudi Critical Infrastructure: The Implications of U.S.-Iranian Escalation"', CSIS Briefs, Aug, p. 5.

Sinkkonen, V. (2018) '"CONTEXTUALIZING THE "TRUMP DOCTRINE"', FIIA Analysis, Nov.

Stein, A. (2016) '"Islamic State Net work in Turkey;Recruitment for the Caliphate"', Atlantic Council.

Stocker, J.R. (2018) '" Historical Legacies of US policy in the Middle East"', in ROBERT JERVIS, F.J.G.J.R.D.N.L.G.F. "Chaos in the liberal order: The Trump Presidency and international politics in the twenty-first century", Columbia University Press. 


\section{QALAAI ZANISTSCIENTIFIC JOURNAL}

A Scientific Quarterly Refereed Journal Issued by Lebanese French University - Erbil, Kurdistan, Iraq

Vol. (5), No (3), Summer 2020

ISSN 2518-6566 (Online) - ISSN 2518-6558 (Print)

Taylor, A. (2019) "No president has recognized Israel's control of the Golan Heights. Trump changed that with a tweet.", 22Mar, [Online], Available: https://www.washingtonpost.com/world/2019/03/22/no-president-has-recognized-israelscontrol-golan-heights-trump-changed-that-with-tweet/.

Terrill, W.A. (2015) '"Iran's strategy for saving Asad"', Middle East Journal, vol. 69, no. 2.

Trump, D. (2015) "Crippled America: how to make America great again" , Thereshhold Edition edition, Imprint of Simon \& Schuster.Inc.

Trump, D.J. (2016a) "Transcript: Donald Trump Expounds on His Foreign Policy Views", 26Mar, [Online], Available: https://www.nytimes.com/2016/03/27/us/politics/donald-trumptranscript.html [4 Dec 2019].

Trump, D.J. (2016b) "Donald Trump Has a Coherent, Realist Foreign Policy", 12Apr, [Online], Available: https://foreignpolicy.com/2016/04/12/donald-trump-has-a-coherent-realistforeign-policy/ [4 Dec 2019].

Trump, D.J. (2017) "Statement by President Trump on the Paris Climate Accord", 1Jun, [Online], Available: https://www.whitehouse.gov/briefings-statements/statementpresident-trump-paris-climate-accord/ [26 Jan 2020].

Trump, D.J. (2018a) "Remarks by President Trump in Briefing at Al Asad Air Base / Al Anbar Province, Iraq", 26Dec, [Online], Available: https://www.whitehouse.gov/briefingsstatements/remarks-president-trump-briefing-al-asad-air-base-al-anbar-province-iraq/ [20 Nov 2019].

Trump, D. (2018b) "After historic victories against ISIS, it's time to bring our great young people home! ", 1Online], Available: https://twitter.com/realDonaldTrump/status/1075528854402256896.

Trump, D. (2018c) "Remarks by President Trump on the Joint Comprehensive Plan of Action", 8May, [Online], Available: https://www.whitehouse.gov/briefings-statements/remarkspresident-trump-joint-comprehensive-plan-action/.

Trump, D. (2019a) "Statement from the President on the Designation of the Islamic Revolutionary Guard Corps as a Foreign Terrorist Organization", 8Apr, [Online], Available: https://www.whitehouse.gov/briefings-statements/statement-president-designationislamic-revolutionary-guard-corps-foreign-terrorist-organization/.

Trump, D.J. (2019b) "Remarks by President Trump on the Death of ISIS Leader Abu Bakr alBaghdadi", 270ct, [Online], Available: https://www.whitehouse.gov/briefingsstatements/remarks-president-trump-death-isis-leader-abu-bakr-al-baghdadi/. 


\section{QALAAI ZANISTSCIENTIFIC JOURNAL}

A Scientific Quarterly Refereed Journal Issued by Lebanese French University - Erbil, Kurdistan, Iraq

Vol. (5), No (3), Summer 2020

ISSN 2518-6566 (Online) - ISSN 2518-6558 (Print)

Trump, D.J. (2019c) "After defeating 100\% of the ISIS Caliphate.", 140ct, [Online], Available: https://twitter.com/realDonaldTrump/status/1183822488192671745.

Trump, D.J. (2019d) "President Trump Delivers Remarks to Troops", 28Nov, [Online], Available: https://www.youtube.com/watch?v=InXrdn3-I-E.

Trump, D.J. (2020a) "Remarks by President Trump on Iran", 8Jan, [Online], Available: https://www.whitehouse.gov/briefings-statements/remarks-president-trump-iran/.

Trump, D.J. (2020b) "Remarks by President Trump on the Killing of Qasem Soleimani", 3Jan, [Online], Available: https://www.whitehouse.gov/briefings-statements/remarks-presidenttrump-killing-qasem-soleimani/.

Trump, D.J. (2020c) "Remarks by President Trump and Prime Minister Netanyahu of the State of Israel in Joint Statements", 28Jan, [Online], Available:

https://www.whitehouse.gov/briefings-statements/remarks-president-trump-primeminister-netanyahu-state-israel-joint-statements/.

U.S. Department of Defense (2020) "Statement by the Department of Defense", 2Jan, [Online], Available:

https://www.defense.gov/Newsroom/Releases/Release/Article/2049534/statement-by-thedepartment-of-defense/.

U.S.Embassy in Syria (2019) "Joint Statement by the Foreign Ministers of the Small Group on Syria", 26Sep, [Online], Available: https://sy.usembassy.gov/joint-statement-by-the-foreignministers-of-the-small-group-on-syria/.

UNSC (2013) "United Nations Securiy Council 2118", 27Sep, [Online], Available: https://www.securitycouncilreport.org/atf/cf/\%7B65BFCF9B-6D27-4E9C-8CD3-

CF6E4FF96FF9\%7D/s res 2118.pdf [1 Sep 2019].

VOA (2018) "AP Explains Turkey's 'Operation Olive Branch' in Afrin, Syria", 22Jan, [Online], Available: $\quad$ https://www.voanews.com/world-news/middle-east-dont-use/ap-explainsturkeys-operation-olive-branch-afrin-syria.

Ward, A. (2019) Lindsey Graham is leading a Senate bill to punish Turkey with crushing sanctions", 10Oct, [Online], Available: https://www.vox.com/2019/10/10/20907934/turkevsyria-kurds-trump-sanctions-graham.

Woodward, B. (2018) "Fear: Trump in the white house", Simon \& Schuster A CBC COMPANY. Yaphe, J.S. (2014) '"Next Steps in Syria"', PRISM, vol. 4. 


\section{QALAAI ZANISTSCIENTIFIC JOURNAL}

A Scientific Quarterly Refereed Journal Issued by Lebanese French University - Erbil, Kurdistan, Iraq

Vol. (5), No (3), Summer 2020

ISSN 2518-6566 (Online) - ISSN 2518-6558 (Print)

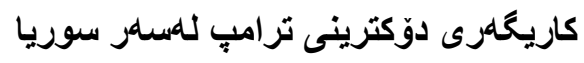

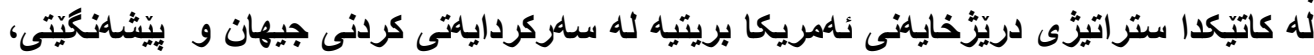

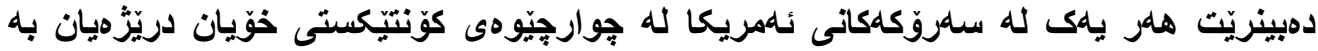

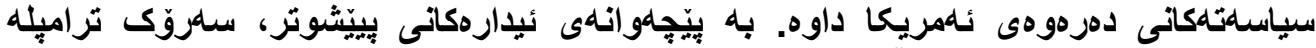

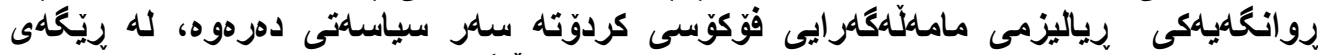

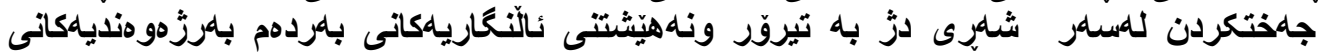

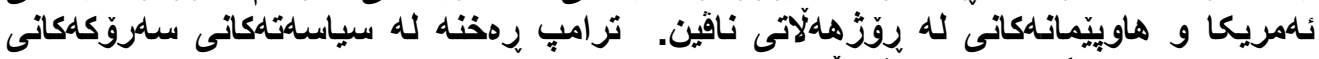

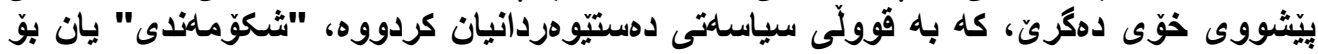

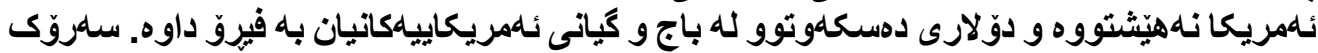

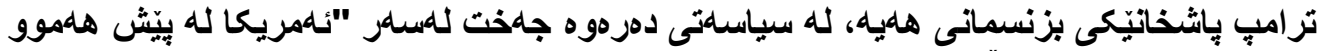

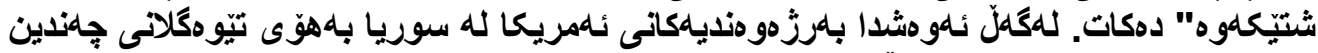

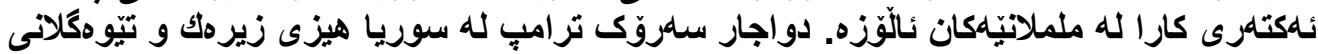

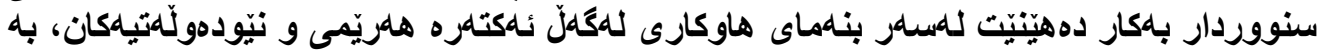

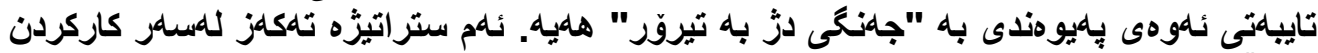

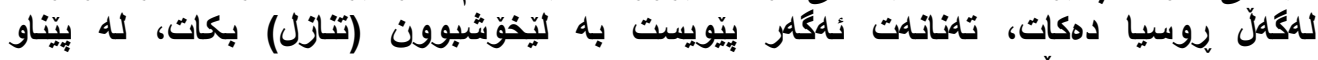

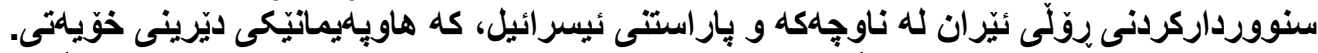

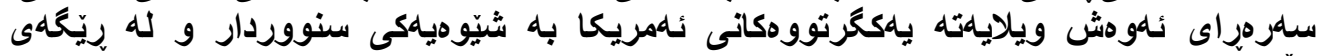

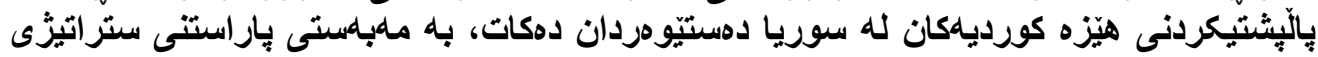
خوّى لله سوريا.

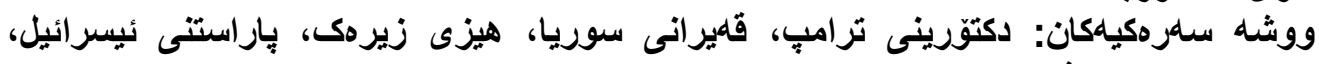

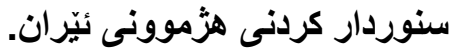

\section{تأثير عقيدة تزامب على سوريا}

سعت السياسة الخارجية للولايات المتحدة إلى الحفاظ على الصدارة على المسرح العالمي، لكن كل

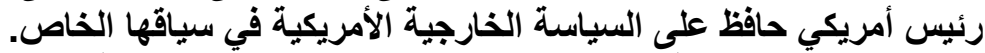

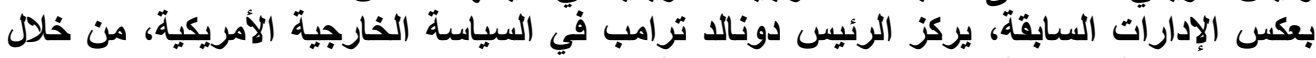

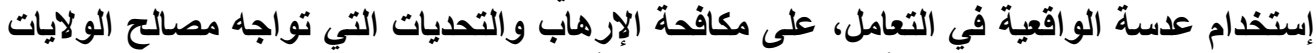

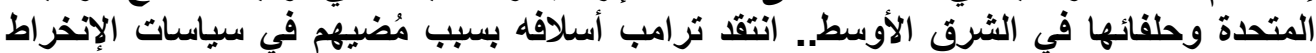

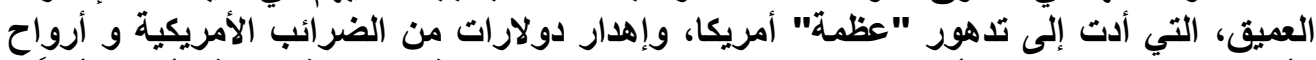

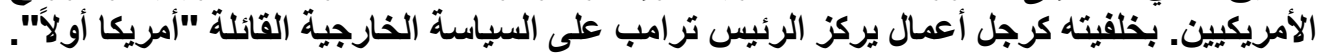

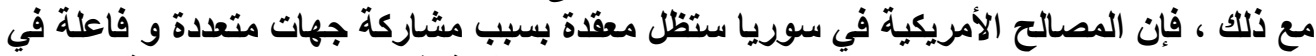

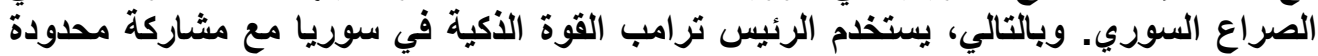

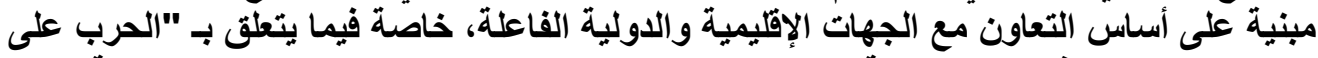

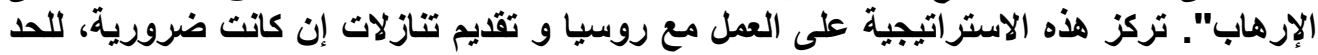




\section{QALAAI ZANISTSCIENTIFIC JOURNAL}

A Scientific Quarterly Refereed Journal Issued by Lebanese French University - Erbil, Kurdistan, Iraq

Vol. (5), No (3), Summer 2020

ISSN 2518-6566 (Online) - ISSN 2518-6558 (Print)

من دور إيران في المنطقة وحماية حليفها القديم، إسرائيل. علاوة على ذلك، تمارس الولايات المتحدة

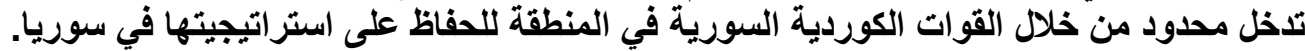

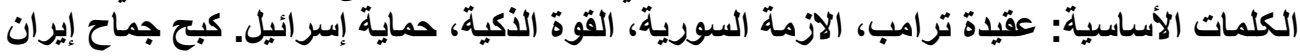

